practical method for grading the cognitive state of patients for the clinician. J Psychiatr Res 1975;12:189-198.

17. Grut M, Fratiglioni L, Viitanen M, Winblad B. Accuracy of the Mini-Mental Status Examination as a screening test for dementia in a Swedish elderly population. Acta Neurol Scand 1993;87:312-317.

18. Price TR, Manolio TA, Kronmal RA, et al. Silent brain infarction on magnetic resonance imaging and neurological abnormalities in community-dwelling older adults. The Cardiovascular Health Study. Stroke 1997;28:1158-1164.

19. Longstreth WT for the Cardiovascular Health Study Collaborative Research Group. Brain abnormalities in the elderly: frequency and predictors in the United States (the Cardiovascular Health Study). J Neural Transm 1998;53(suppl)9-16.

20. Pullicino PM, Pordell R. Computed tomography and magnetic resonance of subcortical ischemic lesions. In: Pullicino PM, Caplan LR, Hommel M, eds. Cerebral Small Artery Disease. New York: Raven Press; 1993:73-92.

21. Pantoni L, Garcia JH. The significance of cerebral white matter abnormalities 100 years after Binswanger's report: a review. Stroke 1995;26:1293-1301.

22. Santamaria Ortiz JS, Knight PV. Review. Binswanger's disease, leukoaraiosis and dementia. Age Ageing 1994;23:75-81.

23. Steingart A, Hachinski VC, Lau C, et al. Cognitive and neurologic findings in demented patients with diffuse white matter lucencies on computed tomographic scan (leukoaraiosis). Arch Neurol 1987;44:36-39.

24. Breteler MMB, van Swieten JC, Bots ML, et al. Cerebral white matter lesions, vascular factors, and cognitive function in a population-based study: the Rotterdam Study. Neurology 1994;44:1246-1252.

25. Cadelo M, Inzitari D, Pracucci G, Mascalchi M. Predictors of leukoaraiosis in elderly neurological patients. Cerebrovasc Dis 1991;1:345-351.

26. Inzitari D, Giordano GP, Ancona AL, Pracucci G, Mascalchi M, Amaducci L. Leukoaraiosis, intracerebral hemorrhage, and arterial hypertension. Stroke 1990;21:1419-1423.

27. Jacqmin H, Commenges D, Letenneur L, Barberger-Gateau P, Dartigues JF. Components of drinking water and risk of cognitive impairment in the elderly. Am J Epidemiol 1994;139: 48-57.

28. Launer LJ, Feskens EJ, Kalmijn S, Kromhout D. Smoking, drinking, and thinking: the Zutphen Elderly Study. Am J Epidemiol 1996;143:219-227.

29. Fraser GE, Singh PN, Bennett H. Variables associated with cognitive function in elderly California Seventh-day Adventists. Am J Epidemiol 1996;143:1181-1190.

30. Tombaugh TN, McIntyre NJ. The Mini-Mental State Examination: a comprehensive review. J Am Geriatr Soc 1992;40: 922-935.

31. Zhu L, Fratiglioni L, Guo Z, Agüero-Torres H, Winblad B, Viitanen M. Association of stroke with dementia, cognitive impairment, and functional disability in the very old: a population-based study. Stroke 1998;29:2094-2099.

32. Moroney JT, Bagiella E, Tatemichi TK, Paik MC, Stern Y, Desmond DW. Dementia after stroke increases the risk of long-term stroke recurrence. Neurology 1997;48:1317-1325.

\title{
Neuro/mages
}

\section{Progressive micrographia in a migraineur}

Timothy J. Counihan, MD, MRCPI,

Richard L. Barbano, MD, PhD, Rochester, NY

In September 1998, a 68-year-old man was evaluated for possible PD. His only symptom was "slowing up a bit" over recent months. His medical history was unremarkable except for a long record of intermittent episodes of visual scintillations, which had been diagnosed as acephalgic migraine. The patient had kept a careful record of the number of these episodes over a 15-year time period (figure).

The figure suggests three possible diagnoses: PD (acquired micrographia); migraine (episodic visual episodes over a 15-year period); and obsessive-compulsive personality disorder.

The figure illustrates the value of examining a patient's handwritten personal records as part of the neurologic examination. In addition, the finding of isolated acquired micrographia may help identify otherwise asymptomatic patients with PD and allow early institution of neuroprotective therapy.

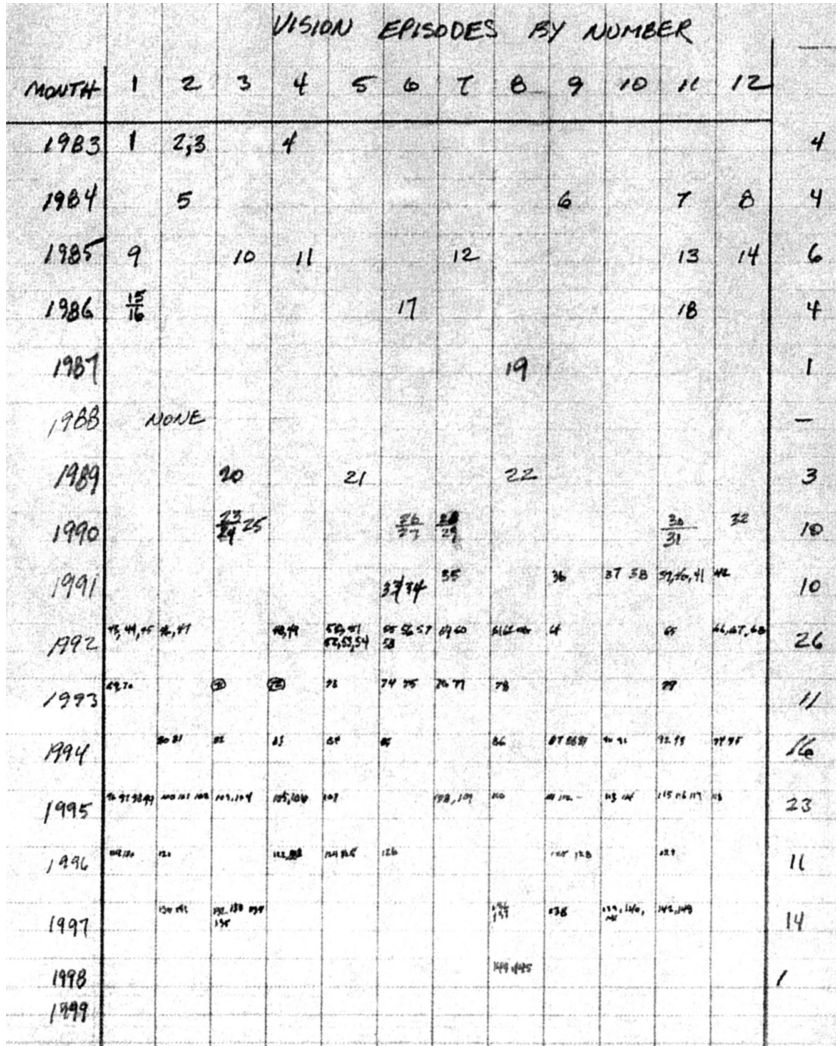

Figure. Patient diary recording the number of migrainous visual episodes experienced over a 15-year period. Between 1991 and 1993, the handwriting becomes progressively more micrographic. 


\section{Neurology}

\section{Progressive micrographia in a migraineur \\ Neurology 2000;54;2107 \\ DOI 10.1212/WNL.54.11.2107}

This information is current as of June 13, 2000

\section{Updated Information \&}

Services

Permissions \& Licensing

Reprints including high resolution figures, can be found at: http://n.neurology.org/content/54/11/2107.full

Information about reproducing this article in parts (figures,tables) or in its entirety can be found online at:

http://www.neurology.org/about/about_the_journal\#permissions

Information about ordering reprints can be found online:

http://n.neurology.org/subscribers/advertise

Neurology ${ }^{\circledR}$ is the official journal of the American Academy of Neurology. Published continuously since 1951, it is now a weekly with 48 issues per year. Copyright . All rights reserved. Print ISSN: 0028-3878. Online ISSN: 1526-632X.

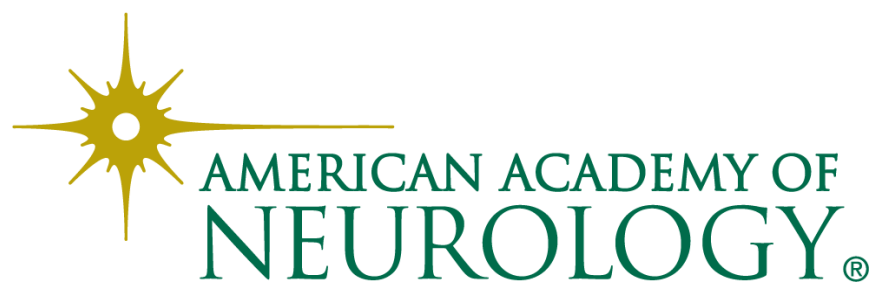

